\title{
Efficiency of inactive vaccines against contagious agalactia in Brazil
}

[Eficiência de vacinas inativadas contra agalaxia contagiosa no Brasil]

\author{
A.C. Campos $^{1}$, E.O. Azevedo ${ }^{2 *}$, M.D.B. Alcântara ${ }^{3}$, R.B.S. Silva ${ }^{4}$, A.A. Cordeiro ${ }^{4}$, \\ A.G. Mamede ${ }^{4}$, M.A. Melo ${ }^{4}$, E. Rosendo Nascimento ${ }^{5}$, R.S. Castro ${ }^{1}$ \\ ${ }^{1}$ Universidade Federal Rural de Pernambuco - Recife, PE \\ ${ }^{2}$ Universidade Federal de Sergipe - São Cristovão, SE \\ ${ }^{3}$ Empresa Estadual de Pesquisa Agropecuária da Paraíba - Soledade, PB \\ ${ }^{4}$ Universidade Federal de Campina Grande - Patos, PB \\ ${ }^{5}$ Faculdade de Veterinária - Universidade Federal Fluminense - Niterói, RJ
}

\begin{abstract}
This paper aims to evaluate the efficiency of three inactive vaccines against contagious agalactia prepared with samples of Mycoplasma agalactiae isolated in Brazil and different adjuvants. Vaccine 1 adsorbed with aluminum hydroxide was administered in 23 goats (Gc1) and 13 sheep (Gov1); vaccine 2 containing Montanide IMS-2215-VG was administered in 22 goats (Gc2) and 12 sheep (Gov2) and vaccine 3, containing Montanide Gel-01 was administered in 22 goats (Gc3) and 12 sheep (Gov3). All animals were negative for $M a$ at indirect ELISA and received two doses of $2 \mathrm{~mL}$ each, subcutaneously, within a 21 day interval. Five animals from each species were used as control. Seventy-five days after the booster, four animals from each vaccinated group and two from the control group were challenged with $5 \mathrm{~mL}$ of $M a$ culture containing $10^{7} \mathrm{cfu} / \mathrm{mL}$, orally and through immersion of the female's udder in lactation. The serological response was analyzed during vaccination days (0 and 21) and at 51, 81, 111, 141 and 171 days after vaccination. The collection and analysis of the challenged animals were conducted at the day of the challenge (D0) and 7, 14, 21, 28, 35, 42, 49 and 56 days after the challenge. The three vaccines induced the production of antibodies, having no significant statistical difference $(\mathrm{p}<0.05)$. Animals from groups Gc1, Gc2 and Gov2 developed higher levels of antibodies, with significant statistical difference compared to the other vaccinated group and control group $(\mathrm{p}<0.05)$. After the challenge, the animals from the control presented an increase in regional lymph nodes and conjunctivitis, mastitis and arthritis. In four vaccinated animals, discrete conjunctivitis and congestion of the episcleral veins was observed. It is concluded that vaccines 1 and 2 induced levels of protective antibodies in goats and sheep, sufficient for clinical protection of the animals submitted to the experimental infection, indicating its use on the prevention of contagious agalactia.
\end{abstract}

Keywords: Mycoplasma agalactiae, goats, sheep, immunization, ELISA

\section{RESUMO}

Este trabalho tem como objetivo avaliar a eficácia de três vacinas inativadas contra agalaxia contagiosa, preparadas com amostra de Mycoplasma agalactiae isolada no Brasil e diferentes adjuvantes. A vacina 1, adsorvida com hidróxido de alumínio, foi administrada em 23 caprinos (Gc1) e 13 ovinos (Gov1); a vacina 2, contendo Montanide IMS-2215-VG, foi administrada em 22 caprinos (Gc2) e 12 ovinos (Gov2); e a vacina 3, contendo Montanide Gel-01 foi administrada em 22 caprinos (Gc3) e 12 ovinos (Gov3). Todos os animais eram negativos para Ma no ELISA indireto e receberam duas doses de $2 \mathrm{~mL}$ cada, por via subcutânea, com intervalo de 21 dias. Cinco animais de cada espécie foram utilizados como controle. Setenta e cinco dias após o reforço, quatro animais de cada grupo vacinado e dois do grupo controle foram desafiados com $5 \mathrm{~mL}$ de cultura de Ma contendo $10^{7} \mathrm{ufc} / \mathrm{mL}$, por via oral e pela imersão dos tetos

Recebido em 24 de abril de 2012

Aceito em 5 de maio de 2013

*Autor para correspondência (corresponding author)

E-mail: edisio@pq.cnpq.br 
das fêmeas em lactação. A resposta sorológica foi analisada nos dias da vacinação (zero e 21) e aos 51, 81, 111, 141 e 171 dias pós-vacinação. As coletas e análises dos animais desafiados foram realizadas no dia do desafio (D0) e sete, 14, 21, 28, 35, 42, 49 e 56 dias pós-desafio. As três vacinas induziram produção de anticorpos, não havendo diferença estatisticamente significativa entre caprinos e ovinos $(P>0,05)$. Animais dos grupos Gc1, Gc2 e Gov2 produziram níveis de anticorpos mais elevados, com diferença estatisticamente significativa em relação aos demais grupos vacinados e ao grupo controle $(P<0,05)$. Após o desafio, os animais do grupo controle apresentaram aumento de linfonodos regionais e conjuntivite, mastite e artrite. Em quatro animais vacinados, foi observada discreta conjuntivite $e$ congestão dos vasos episclerais. Conclui-se que as vacinas 1 e 2 induziram níveis de anticorpos protetores em caprinos e ovinos suficientes para proteção clínica dos animais submetidos à infecção experimental, podendo ser indicadas para prevenção da agalaxia contagiosa.

Palavras-chave: Mycoplasma agalactiae, caprina, ovina, imunização, ELISA

\section{INTRODUCTION}

The contagious agalactia (CA) is a disease characterized by mastitis, followed by agalactia, polyarthritis and keratoconjunctivitis, caused mainly by Mycoplasma agalactiae (Ma). The infection spreads rapidly in the herd, affecting $30-85 \%$ of the animals in a short period of time, causing considerable losses, especially due to a high reduction in milk production and animal deaths. The disease is endemic in countries from Europe, Africa, central and west regions of Asia and is an emerging disease in countries from the American continent and in Japan (Azevedo et al., 2006; OIE, 2011). In Brazil, the isolation of the $M a$ was performed initially on sick goats in 2001, in the state of Paraiba (Nascimento et al., 2002) and soon the infection spread to Pernambuco and Rio Grande do Norte States (Azevedo et al., 2006).

The use of antibiotics for a period of five to ten days reduces the main clinical signals of the disease, but does not eliminate the bacteria, favoring its dissemination through the commercialization of the asymptomatic animals (Azevedo et al., 2006).

Disease control alternatives such as the use of biotherapeutic (Marinho, 2008) and the separation of kids and lambs at the moment they are born without offering colostrum and milk from uninfected animals (Alcântara et al., 2003) have been investigated.

In Europe, vaccination has been adopted since the 1970s (Foggie et al., 1970; Foggie et al., 1971). However, only after the 1990 s did this practice become intensively used. Most of the vaccines are prepared only with $M a$, but others may contain an association of $M a$ with $M$. mycoides subsp. mycoides LC, M. putrefaciens, M. capricolum subsp. capricolum (León Vizcaíno et al., 1995; Tola et al., 1999; Greco et al., 2002; de la Fe et al., 2007; Buonavoglia et al., 2008; Buonavoglia et al., 2010).

The use of aluminum hydroxide or mineral oil as adjuvants for the vaccines interferes with the time of immunological stimulation and, consequently, the protection of the animals. Regarding the contagious agalactia, it has been observed that the vaccines containing aluminum hydroxide protect for approximately six months while those with mineral oil may reach 11 months (Buonavoglia et al., 1998; de la Fe et al., 2007). However, attention must be taken to the existence of a major reaction on the inoculation spot, with the creation of persistent nodules when an oily adjuvant is used (Buonavoglia et al., 2008).

Immunization as a strategy to prevent and control CA in Brazil is not yet a reality because of the inexistence of the vaccine in the country. Therefore, the purpose of this paper was to develop and evaluate the efficiency of vaccines against $M a$ prepared with different adjuvants.

\section{MATERIAL AND METHODS}

A $M a$ (P20BrPB03) previously isolated and characterized (Campos, 2012) sample was cultivated for 96 hours in modified Hayflick broth and enriched with $20 \%$ of inactive equine serum at $37^{\circ} \mathrm{C}$ in microaerophile. The determination of colony former unities (cfu) was performed by a series of dilutions $\left(10^{-1}\right.$ to $\left.10^{-6}\right)$ in a liquid environment and sowing in a solid 
environment, with a reading after 96 hours of incubation.

The cultivation was then centrifuged twice at $3.800 \mathrm{~g}$ for an hour and resuspended in PBS, $\mathrm{pH}$ 7.6. The viability of the $M a$ was quantified through the sowing of the material in modified agar Hayflick, in the conditions described previously. The protein concentration of the antigen was determined through a 280nm filter (BioPhotometer plus, Eppendorf, Germany). The washed cultivation was stored at $-20^{\circ} \mathrm{C}$.

The bacterial suspension obtained was adjusted using PBS, pH 7.6 for a protein concentration pre-inactivation of $5 \mathrm{mg}$ per dose of the vaccine and inactivated with formaldehyde at $0.4 \%(\mathrm{v} / \mathrm{v})$ for 24 hours at $37^{\circ} \mathrm{C}$. The inactivated suspension was divided in three aliquots and then adsorbed under constant and mechanical agitation for three hours at room temperature, with its adjuvant:

a) Vaccine 1: Aluminum hydroxide gel in a $6 \mathrm{mg} / \mathrm{mL}$ concentration;

b) Vaccine 2: Montanide IMS $2215 \mathrm{VG}$ in a $25 \%$ (v/v) concentration;

c) Vaccine 3: Montanide Gel 01 at 5\% (v/v);

The vaccines were stored at $4^{\circ} \mathrm{C}$ during the experimental period.

For the sterility test, $200 \mu \mathrm{L}$ from each vaccine was sowed in modified agar Hayflick and cultivated as described above. Besides that, the samples were sowed in Blood agar and Sabouraud Chloramphenicol, with incubation at $37^{\circ} \mathrm{C}$ and $22^{\circ} \mathrm{C}$, respectively, for 21 days. By the end of the incubation period cultures were macro and microscopically examined in order to observe the presence of Mycoplasma or other microorganisms. The safety of the vaccines and the controls was tested through the subcutaneous administration of $2 \mathrm{~mL}$ of each vaccine in one goat (1 goat/vaccine or control), with clinical observation for 45 days.

For the formation of the experimental groups a selection of goats and sheep was made from herds with no clinical history of the disease and with monitoring for the absence of anti-Ma antibodies through an indirect ELISA, as described by Campos et al. (2009).

Seventy-two goats and 42 sheep with an undefined racial pattern, males and females, with ages ranging from 6 to 48 months were randomly and homogeneously distributed in eight groups: Gc1 (23 goats) and Gov1 (13 sheep) received vaccine 1 ; Gc2 (22 goats) and Gov2 (12 sheep) received vaccine 2; Gc3 (22 goats) and Gov3 (12 sheep) received vaccine $3 ; \mathrm{Gc} 4$ (5 goats) and Gov4 (5 sheep) were used as control.

Two doses of $2 \mathrm{~mL}$ of each vaccine were subcutaneously administered at the right and left side with an interval of 21 days. The control group received the same vaccine protocol using sterile PBS as inoculum. On the day of the first dose and at each 15 day period the place of inoculation was inspected and measured using a digital skin measurement equipment.

For the challenge, four animals from each vaccinated group and two from the control group were selected randomly and transferred to a pen at the Veterinary Hospital from the Federal University of Campina Grande, 65 days after the vaccine's second dose. The animal's adaptation period was of 10 days. The experimental challenge was conducted by the administration of $5 \mathrm{~mL}$ from the cultivation of sample P20BrPB03of $M a$ orally containing $10^{7} \mathrm{cfu} / \mathrm{mL}$. For the females under lactation a second challenge protocol was added, which consisted of immersing the udders in a solution containing bacterial culture.

The animals were observed daily for 60 days, with a detailed clinical exam in alternated days on the first week after challenge, with special attention to the temperature, lymph nodes, mammary gland, articulation and eyes, and weekly collection of blood serum. From the animals that presented clinical signals, samples were collected for bacterial cultivation.

To evaluate antibody levels, blood samples from the vaccinated groups were collected from each animal on the day of the first dose (T0), 15 days after the first dose (15 dpv), 21 days after the first vaccination, and, afterwards, monthly for five months $(51,81,111,141,171 \mathrm{dpv})$. From the challenge group, collections were made on the challenge day (D0) and weekly during the experiment $(7,14,21,28,35,42,49$ and 56 days after the challenge). The serums were stored at $20^{\circ} \mathrm{C}$ until processing.

To detect antibodies anti- $M a$ indirect ELISA was utilized. The cut-off point of the test was $5.9 \%$ of 
optical density (OD) average from the positive control. The result of each tested serum was expressed as a percentage of the average OD of three repetitions of positive control (Campos et al., 2009).

For statistical analysis the effect of the treatment, the day of the observation and the interaction between the treatments were considered through Tukey test, using SAS (1999) software.

\section{RESULTS AND DISCUSSION}

The vaccines proved to be appropriate regarding its sterility and innocuousness, as there was no growth of bacteria and fungus on the in vitro test and they didn't induct systemic reactions or clinical signals of $\mathrm{AC}$ on the in vivo test.
All vaccinated animals showed an increase of pre-scapular lymph nodes near the inoculation site, staying that way until the sixth day after vaccination. Animals from $\mathrm{Gc} 2$ and Gov2 showed an increase of temperature and pain at the inoculation site, which disappeared around the fourth day after vaccination. All vaccinated animals presented a nodule at the site where the vaccine was introduced, as described in Tab. 1, but there was no significant statistical difference between the reactions on the vaccination site $(\mathrm{P}>0.05)$. Abscess or other kinds of undesirable reactions were not observed during the experimental period. 60 days after the vaccination the diameter of the inoculation spot was practically the same from the beginning of the vaccination (Tab. 1). Studies conducted by Buonavoglia et al. (2008) revealed similar increases as those observed on this study, but the reactions remained for a longer period.

Table 1. Size of local reaction (in $\mathrm{mm}$ ) and persistence of the nodule (in days) on the inoculation site according to the vaccine used on goats (Gc) and sheep (Gov)

\begin{tabular}{llccccc}
\hline \multirow{2}{*}{ Animal/ vaccine } & \multicolumn{5}{c}{ Diameter of the local reaction according to the period of observation (in days) } \\
\cline { 2 - 7 } Goats & 0 & 15 & 30 & 45 & 60 \\
\hline \multirow{3}{*}{ Sheep } & Gc1 & $3.6^{*}$ & 13.0 & 8.3 & 6.2 & 3.7 \\
& Gc2 & 4.1 & 12.2 & 7.6 & 4.2 & 4.5 \\
& Gc3 & 3.4 & 10.0 & 69 & 5.2 & 3.6 \\
\hline
\end{tabular}

* Value averages expressed in mm. p>0.05

Figures 1 and 2 represent levels of antibody production developed by the animals during the vaccination. It is possible to verify a progressive increase after the first dose in all vaccinated groups, with higher levels 30 days after the second dose $(51 \mathrm{dpv})$, showing the need for the application of a second dose of the vaccine. The animals from the control group remained negative during the experimental period.

It can be observed that all three vaccines induced the production of antibodies, where groups Gc1 and Gc2 were similar within each other, producing higher levels, statistically significant in relation to animals from group Gc3 and Gc4 $(\mathrm{P}<0.05)$ when analyzed with the Tukey test.
The immunological response of the immunized sheep showed a different behavior from goats. Only animals from group Gov2 showed a statistically significant difference when compared to the rest of the vaccinated groups and to the control $(\mathrm{P}<0.05)$. Similar results to those described in this paper were described by Alcântara et al. (2013) and Buonavoglia et al. (2010) when they used an oily adjuvant on the vaccine. The Montanide IMS-2215-VG contains organic immunostimulant substances in its composition and this formulation has probably stimulated a more efficient immunological response. Swine and mice vaccinated with products that contained this adjuvant have presented higher antibody titers than the vaccines that use aluminum hydroxide (Seppic, 1999). 


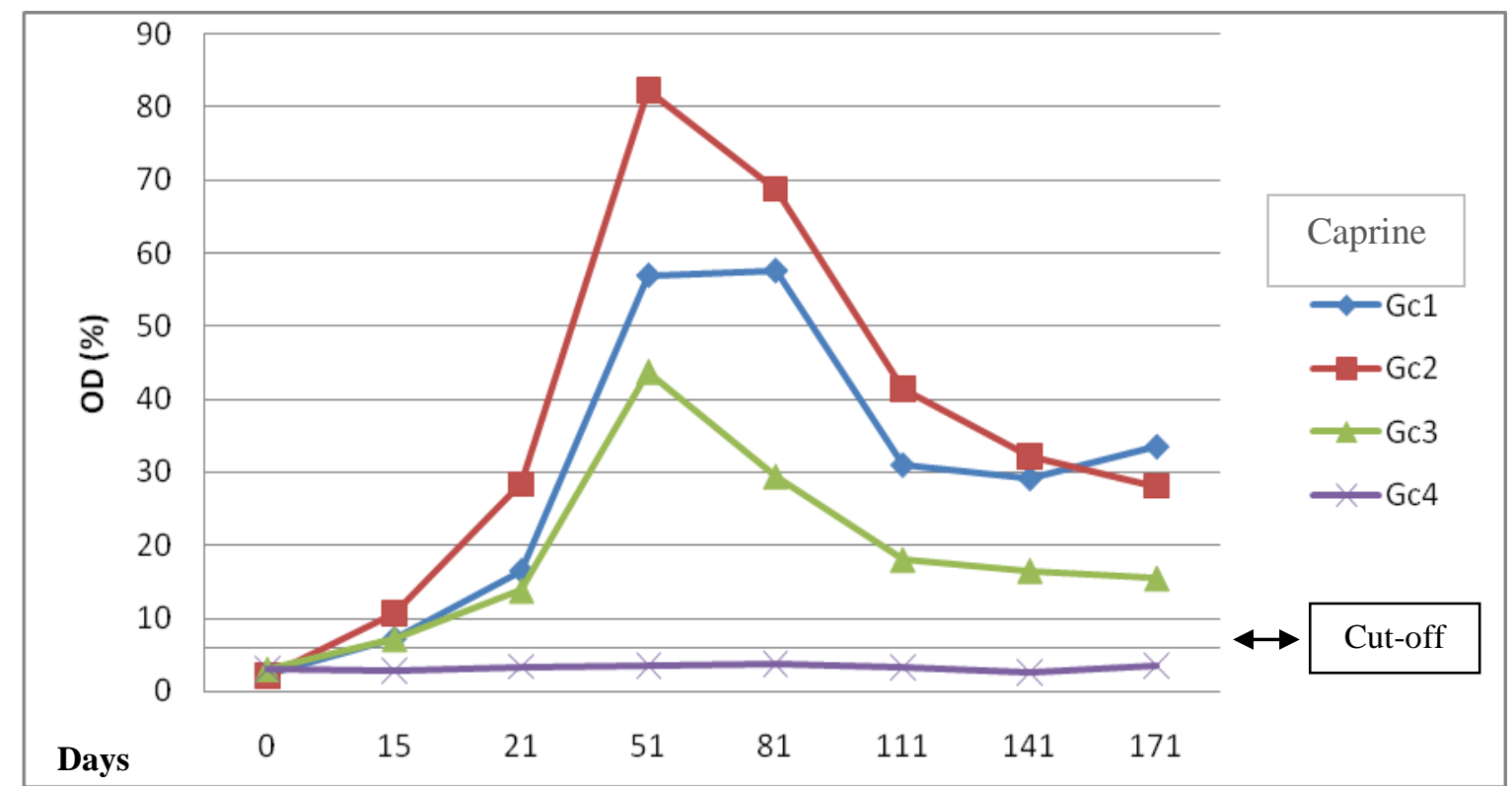

Figure 1. Levels of antibodies anti-Ma analyzed by the ELISA-Gs in vaccinated goats against contagious agalactia. $\mathrm{Gc} 1$ = goats immunized with vaccine $1 ; \mathrm{Gc} 2=$ goats immunized with vaccine 2 ; Gc3 = goats immunized with vaccine $3 ; \mathrm{Gc} 4=$ non immunized goats (control). Cut-off $=5.9 \%$.

$0=$ day of 1 st dose; $15=15$ days after 1 st dose; 21 = day of 2 nd vaccination, 21 days after 1 st dose; 51 to $171=$ days after 1 st dose.

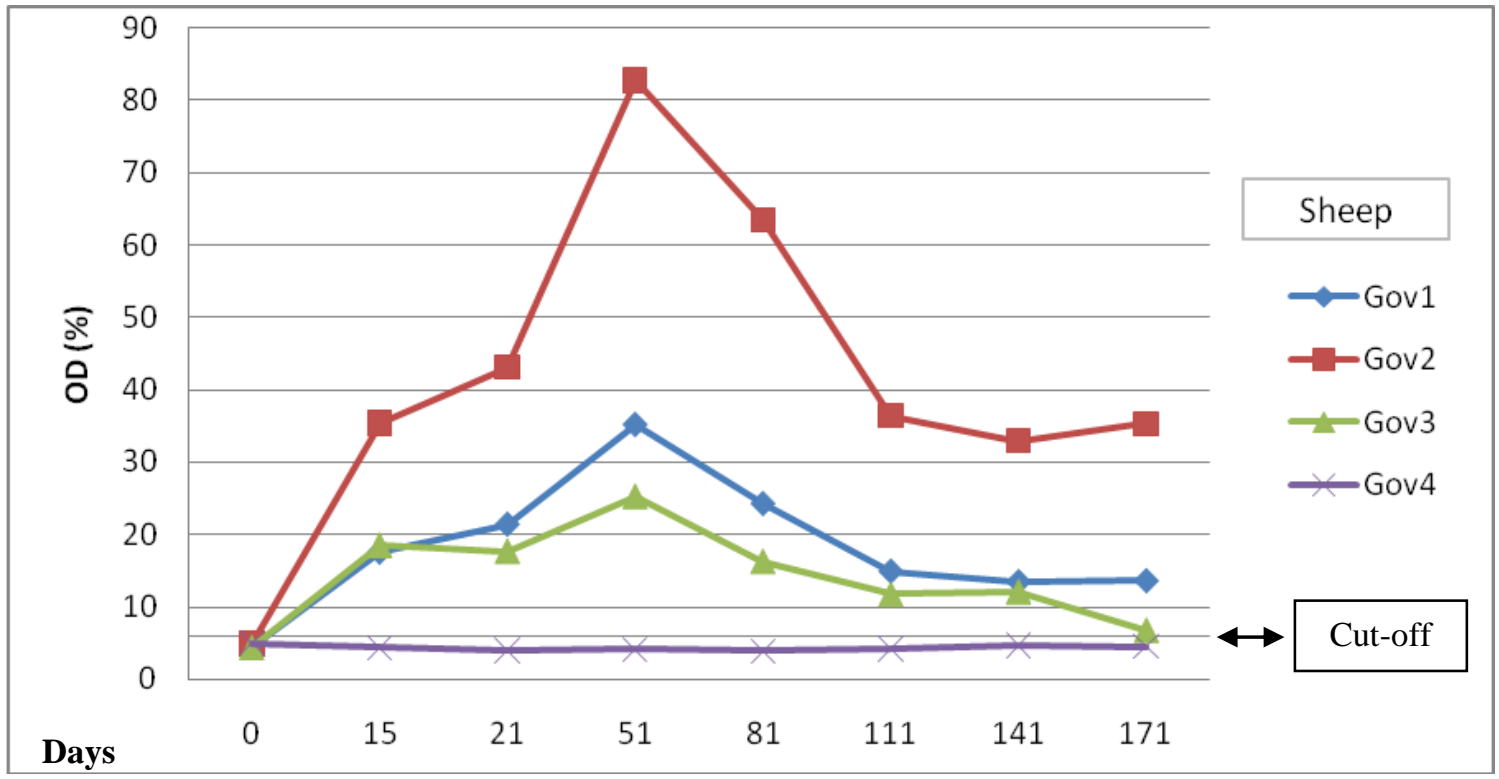

Figure 2. Levels of antibodies anti-Ma analyzed by the ELISA-Gs in vaccinated sheep against contagious agalactia. Gov1 = sheep immunized with vaccine 1; Gov2 = sheep immunized with vaccine 2; Gov3 = sheep immunized with vaccine 3 ; Gc4 $=$ non immunized sheep (control). Cut-off $=5.9 \%$.

$0=$ day of 1 st dose; $15=15$ days after 1 st dose; $21=$ day of 2 nd vaccination (21 days after 1 st dose); 51 to 171 = days after 1 st dose. 
Although the values of optical density have been slightly higher in goats compared to sheep, there was no significant statistical difference between both species ( $\mathrm{P}>0.05$; data not presented). However, this slight difference may be related to the origin of the sample used for the production of the vaccine. Sotoodehnia et al. (2005) observed that sheep presented higher titers than goats when immunized with a vaccine of ovine origin.

Although animals from group Gc1 have presented lower levels of antibodies, they are still higher than those from the $\mathrm{Gc} 3$ and $\mathrm{Gc} 4$. Considering the low cost of the aluminum hydroxide, this product may be an option to be used on goats. An alternative to be applied in future studies would be to include immunostimulant substances, such as saponin, in the composition of the vaccine (De la Fe et al., 2007) or to associate different types of adjuvants on the same vaccine.

Regarding the persistence of the antibodies, in a study using a vaccine containing three types of oils, Buonavoglia et al. (2010) verified that sheep vaccinated and challenged at 5 and 8 months after the booster did not develop clinical AC signals. However, they presented a decrease on the antibodies titers even after the challenge, unlike animals from the control group, which had clinical signals and increased the levels of antibodies. Tola et al. (1999) by using various types of inactive substances in vaccines against contagious agalactia, demonstrated that saponin showed great capacity of keeping the immunogenic proteins and antibodies levels for more than six months.

The inactive vaccines stimulate lower and less persistent antibodies titers, and must be repeated in shorter periods, preferably before and after parturition (Leon Vizcaino et al., 1995). This is probably the vaccinal scheme that should be adopted in Brazil.

After the challenge the antibody levels from the vaccinated goats presented a rapid increase in groups Gc2 and Gc3, unlike group Gc1 which presents a decrease during the subsequent weeks. Animals from the control group only presented antibody levels above the cut-off point by the third week after the infection, keeping that growth until the sixth week, when it remains stable but with a tendency towards reduction. All groups started a reduction on the antibody levels by the fourth week after the challenge, however, groups Gc2 and Gc3 kept higher levels (Figure 3).

The ovine behavior was different from goats. Only Gov2 presented a response after the challenge, achieving the peak from the $14^{\text {th }}$ to the $28^{\text {th }}$ day, when they initiated a reduction in antibodies (Figure 4). These results are similar to Castro-Alonso et al. (2009) who analyzed the immunological response of goats experimentally infected though intramammary use and then verified that the anti-Ma antibodies were presented on the 11th day after infection and persisted until the 32nd day. According to Hasso and Al-Omran (1994), the inoculation way might interfere on the antibodies production time against $M a$.

In our study, $16.7 \%(4 / 24)$ of the vaccinated animals presented a discrete congestion of episcleral veins and of the ocular mucus, observed on both species in different periods after challenge. These signals were observed in sheep from Gov1 between the 8th and 15th day and in a goat from Gc1 between the 8th and 54th day after the challenge. In group Gov2, one sheep presented the same signals from the 42nd to the 49th day after the challenge and in group Gov3 one sheep presented it from the 8th to the 15th day. Four animals from the challenged control group presented one or more of the following clinical signals: temporary increase of the retropharyngeal, submandibulars, prescapulars and supramammary lymph nodes, conjunctivitis, cracking on the thoracic limbs, arthritis and mastitis. The most serious cases were found on a goat, which presented mastitis with reduction of milk production 28 days after the challenge, and on a sheep, which presented temporary arthritis. It was possible to isolate the $M a$ from the secretion of the mammal gland of only two animals, one goat from the control group that presented mastitis and one vaccinated goat from Gc3. On this animal, the isolation was obtained seven days before and seven days after parturition. 


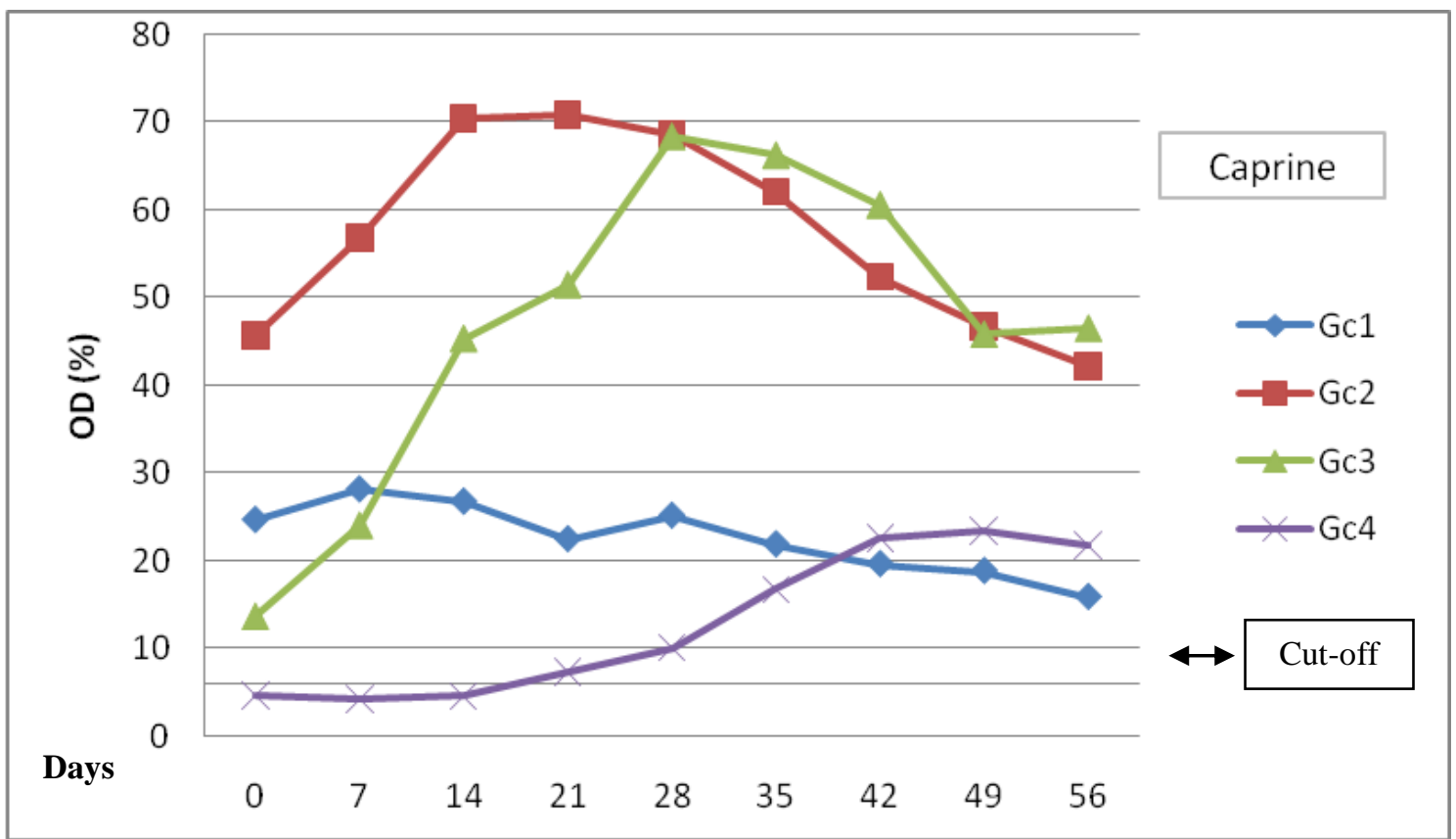

Figure 3. Comparison of immune response through ELISA-Gs of the group of challenged goats.

$\mathrm{Gc} 1$ = goats immunized with vaccine $1 ; \mathrm{Gc} 2$ = goats immunized with vaccine $2 ; \mathrm{Gc} 3$ = goats immunized with vaccine $3 ; \mathrm{Gc} 4=$ non immunized goats (control). Cut-off $=5.9 \%$.

$\mathrm{D} 0=$ day of the challenge (75 days after the second dose of the vaccine); D1 to D8 = days of collection (in days) after the challenge, performed with an interval of 7 days.

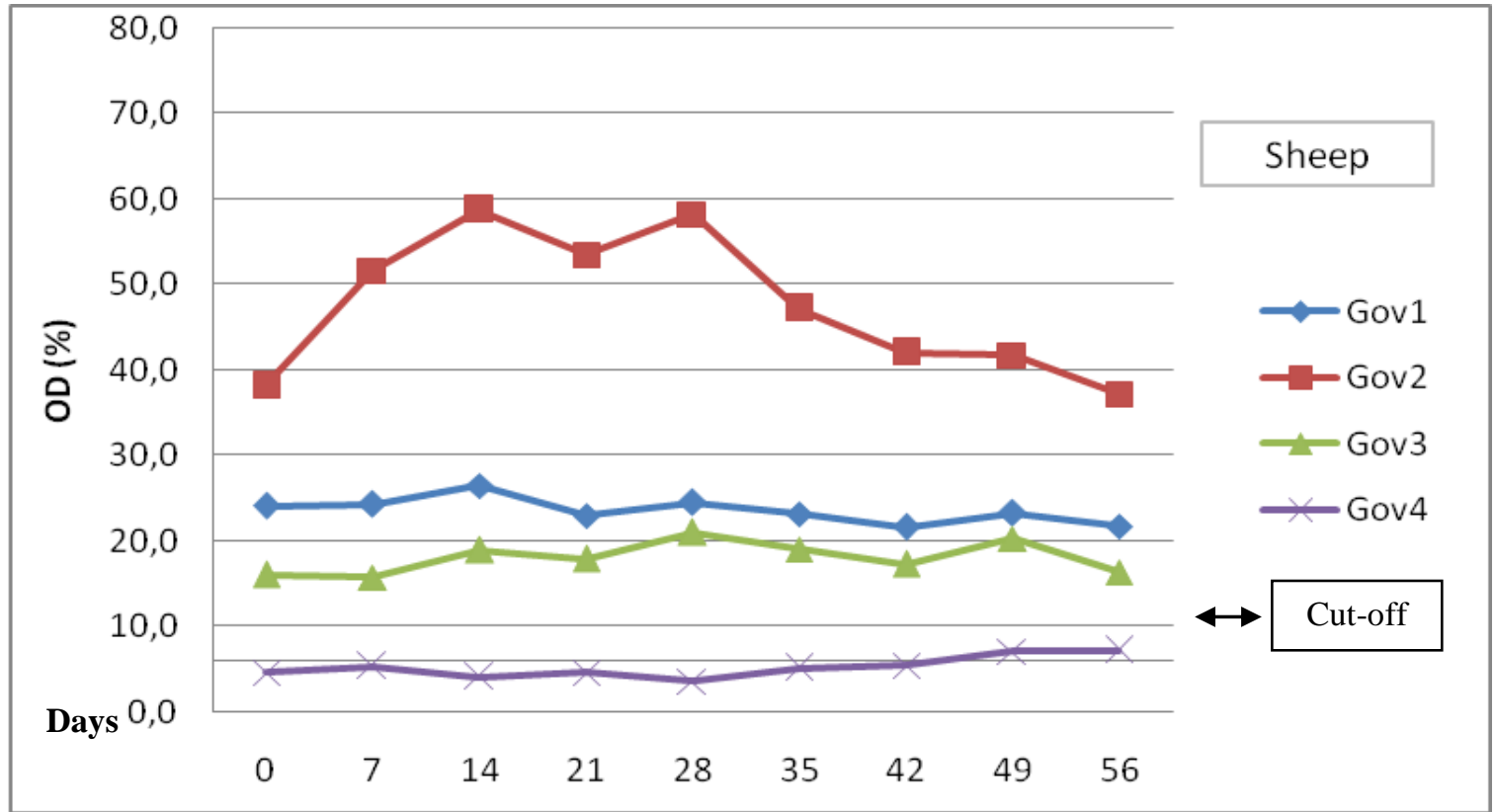

Figure 4. Comparison of immune response through ELISA-Gs of the group of challenged sheep.

Gov1 = sheep immunized with vaccine 1 ; Gov2 = sheep immunized with vaccine 2; Gov3 = sheep immunized with vaccine 3 ; Gov4 = non immunized sheep (control). Cut-off $=5.9 \%$.

$\mathrm{D} 0=$ day of the challenge ( 75 days after the second dose of the vaccine); D1 to D8 = days of collection (in days) after the challenge, performed with an interval of 7 days. 
One sheep from Gov3 remained with low antibody levels throughout the experimental period and even after the challenge the titers did not increase significantly. This animal tears presented shedding and congestion of the episcleral veins, showing a probable immunologic incompetence.

\section{CONCLUSIONS}

The goats and sheep immunized with vaccines 1 and 2 produced antibodies anti-Ma sufficient to prevent the appearance of the clinical signals of the contagious agalactia on most of the animals under the experimental infection. Further studies should be conducted to confirm the effectiveness of the vaccines on natural infection.

\section{ACKNOWLEDGMENTS}

To Ministério da Agricultura, Pecuária e Abastecimento (MAPA), Conselho Nacional de Desenvolvimento Científico e Tecnológico (CNPq), Fundação de Amparo à Ciência e Tecnologia do Estado de Pernambuco (FACEPE), for the financial support and scholarships. To Mr. José Gedeão Rodrigues dos Santos for providing the animals and for contributing throughout the entire project. To Tereza Emmanuelle F. Rotondano for statistical analysis.

\section{REFERENCES}

ALCÂNTARA, M.D.B. CAMPOS, A.C; MELO, M.A. et al. Resposta imunológica em caprinos vacinados contra agalaxia contagiosa. Pesq. Vet. Bras., v.33, p.561-564, 2013.

ALCÂNTARA, M.D.B.; AZEVEDO, E.O.; FARIAS, A.A. et al. Indução de parto e separação das crias para controle da agalaxia contagiosa em caprinos. In: CONGRESSO LATINO AMERICANO DE BUIATRIA, 11., 2003, Salvador. Anais... Salvador: [s.n.] 2003. p.71. (Resumo).

AZEVEDO, E.O; ALCÂNTARA, M.D.B.; NASCIMENTO, E.R. et al. Contagious agalactia by Mycoplasma agalactiae in small ruminants in Brazil: first report. Braz. J. Microbiol., v.37, p.576-581, 2006.

BUONAVOGLIA, D.; FASANELLA, A.; SAGAZIO, P. et al. Persistence of antibodies to Mycoplasma agalactiae in vaccinated sheep. New Microbiol., v.21, p.209-212, 1998.
BUONAVOGLIA, D.; GRECO, G.; QUARANTA, V. et al. An oil-emulsion vaccine induces full-protection against Mycoplasma agalactiae infection in sheep. New Microbiol., v.31, p.117-123, 2008.

BUONAVOGLIA, D.; GRECO, G.; CORRENTE, M. et al. Long-term immunogenicity and protection against Mycoplasma agalactiae induced by an oil adjuvant vaccine in sheep. Res. Vet. Sci., v.88, p.1619, 2010.

CAMPOS, A.C. Produção e avaliação de vacina contra agalaxia contagiosa. 2012.75f. Tese (Doutorado em Ciência Veterinária) - Departamento de Medicina Veterinária, Universidade Federal Rural de Pernambuco, Recife, PE.

CAMPOS A.C.; TELES J.A.A.; AZEVEDO E.O. $e t$ $a l$. ELISA protein $\mathrm{G}$ for the diagnosis of contagious agalactia in small ruminants. Small Rumin. Res., v.84, p.70-75, 2009.

CASTRO-ALONSO, A.; RODRÍGUEZ, F.; DE LA FE, C. et al. Correlating the immune response with the clinical-pathological course of persistent mastitis experimentally induced by Mycoplasma agalactiae in dairy goats. Res. Vet. Sci., v.86, p.274-280, 2009.

DE LA FE, C.; ASSUNÇÃO, P.; SAAVEDRA, P. et al. Field trial of a combined vaccine against caprine contagious agalactia: Humoral immune response in lactating goats. Vet. J., v.174, p.610-615, 2007.

FOGGIE, A.; ETHERIDGE, J.R.; ERDAB, 0.; ARISOY, F. Contagious agalactia of sheep and goats preliminary studies on vaccines. J. Comp. Path., v.80, p.345-359, 1970.

FOGGIE, A.; ETHERIDGE, J.R.; ERDAB, 0.; ARISOY, F. Contagious agalactia of sheep and goats immunity of lactating ewes vaccinated before mating with live or dead vaccines. J. Comp. Path., v.81, p.393-400, 1971.

GRECO, G.; CORRENTE, M.; BUONAVOGLIA, D. et al. Inactivated vaccine induces protection against Mycoplasma agalactiae infection in sheep. New Microbiol., v.25, p.17-20, 2002.

HASSO, S.A.; AL-OMRAN, A.H. Antibody response patterns in goats experimentally infected with Mycoplasma agalactiae. Small Rumin. Res., v.14, p.79-81, 1994.

LEON VIZCAINO L.; GARRIDO ABELLAN, F.; CUBERO PABLO, M.J.; PERALES, A. Immunoprophylaxis of caprine contagious agalactia due to Mycoplasma agalactiae with an inactivated vaccine. Vet. Rec., v.137, p.266-269, 1995. 
MARINHO, M.L. Ação terapêutica do bioterápico de Mycoplasma agalactiae em caprinos com agalaxia contagiosa dos ovinos e caprinos. 2008. 118f. Tese (Doutorado em Ciência Veterinária) - Departamento de Medicina Veterinária, Universidade Federal Rural de Pernambuco, Recife, PE.

NASCIMENTO, E.R.; BARRETO, M.L.; PLATENIK, M.O. et al. Contagious agalactia by Mycoplasma agalactiae in goats in Brazil. Etiologic study. In: CONGRESS OF THE INTERNATIONAL ORGANISATION FOR MYCOPLASMOLOGY (IOM). 14., 2002. Vienna. Proceedings... Vienna:[s.n.] 2002. p.45-46.

OIE - WORLD Organization for Animal Health, World Animal Health Information Database (WAHID) Interface, 2011. Available in: <http://web.oie.int/ wahis/public.php>. Accessed on: 5 fev. 2012.
SEPPIC. Montanide ${ }^{\circledR}$ IMS, Doc. P/1397/GB/01/ SEP99. Available in: <http://www.seppic.com> 1999. Accessed on: 3 jul. 2008.

SOTOODEHNIA, A.; MOAZENI JULA, G.; MADANI, R. et al. Determination of Antibody Response against Inactivated Agalactia Vaccine in Small Ruminants. Arch. Razi Ins., v.60, p.67-75, 2005.

STATISTICAL ANALYSIS SYSTEM

SAS. SAS/STAT user's guide: statistics. Cary: SAS Institute, 1999. 943p.

TOLA, S.; MANUNTA, D.; ROCCA, S. et al. Experimental vaccination against Mycoplasma agalactiae using different inactivated vaccines. Vaccine, v.17, p.2764-2768, 1999. 